\title{
Age, sex, and region adjusted concentrations of chromium and nickel in lung tissue
}

\author{
Heinrich Kollmeier, Jörg W Seemann, Günter Rothe, Klaus-Michael Müller, Peter Wittig
}

\begin{abstract}
Chromium (Cr) and nickel ( $\mathrm{Ni}$ ) concentrations were measured in lung tissue from 110 random necropsies by means of atomic absorption spectrometry. The subjects originated from the Ruhr district (Bochum (71 cases) and Dortmund (16 cases) areas), which has been defined as a particular pollution area with locally high $\mathrm{Cr}$ and $\mathrm{Ni}$ emissions, and from Münster and vicinity (23 cases). The $\mathrm{Cr}$ and $\mathrm{Ni}$ concentrations in lung tissue of the subjects from the Ruhr district (3.09 (SD 2.99) $\mu \mathrm{g} \mathrm{Cr} / \mathrm{g}$, 0.65 (SD 0.94) $\mu \mathrm{g} \mathrm{Ni} / \mathrm{g}$ dry weight of lung) were 4.8 and 2.8 times higher than those from Münster (0.66 (SD 0.49) $\mu \mathrm{g} \mathrm{Cr/g,} \mathrm{0.17} \mathrm{(SD} \mathrm{0.11)}$ $\mu \mathrm{g} \mathrm{Ni} / \mathrm{g}$ dry weight of lung). Concentrations of $\mathrm{Cr}$ and $\mathrm{Ni}$ in men were twice those in women. All data showed an age dependent increase of $\mathrm{Cr}$ and $\mathrm{Ni}$ in the lung (about $2 \cdot 4 \%$ a year for $\mathrm{Cr}$ and $3 \%$ a year for $\mathrm{Ni}$ ) and $\mathrm{Cr}$ and $\mathrm{Ni}$ values showed a high correlation $(r \geq 0.9)$. Thus it was possible to calculate age, sex, and region adjusted expected values of pulmonary $\mathrm{Cr}$ and $\mathrm{Ni}$ concentrations, and to identify the difference between expected and observed values. This might be helpful to interpret measurements in individual cases and in epidemiological studies. With this procedure the six cases of bronchial carcinoma in the series were shown to have pulmonary $\mathrm{Cr}$ and $\mathrm{Ni}$ concentrations that were mostly well above the predicted values, and it was possible to give a rough estimate of the degree of deviation.
\end{abstract}

Measurements of tissue chromium ( $\mathrm{Cr}$ ) and nickel (Ni) concentrations are important in industrial

Federal Institute for Occupational Safety and Health, Dortmund, FRG

H Kollmeier, J W Seemann, P Wittig

Zentrum für Umfragen, Methoden und Analysen e V, Mannheim, FRG

G Rothe

Institut für Pathologie der Berufsgenossenschaftlichen Krankenanstalten "Bergmannsheil"Universitätsklinik, Bochum, FRG

K-M Müller medicine because raised concentrations of these metals in samples of lung tissues obtained at necropsy are often regarded as evidence that the subject was exposed to dusts or fumes containing $\mathrm{Cr}$ or $\mathrm{Ni}^{1{ }^{1-3}}$ Clinical interpretations of such measurements have been restricted by a lack of reliable data from nonexposed control subjects. ${ }^{45}$ Because the air of industrial and residental areas is constantly polluted by at least small amounts of $\mathrm{Cr}$ and $\mathrm{Ni}$, and as these metals are to some extent accumulated in lung tissue, the question arises as to how to define non-exposed subjects. Of the whole range of necropsy cases those dying perinatally might be considered as such, although $\mathrm{Cr}$, particularly as $\mathrm{Cr}(\mathrm{III})$, and $\mathrm{Ni}$ (II) cross the placenta. ${ }^{6}$ We have previously demonstrated that the pulmonary $\mathrm{Cr}$ and $\mathrm{Ni}$ content of a stillbirth was very low whereas that of adults was much higher and increased with age. ${ }^{7}$ The present paper provides calculations to assess the conditions that affect pulmonary $\mathrm{Cr}$ and $\mathrm{Ni}$ content and that should be taken into consideration when interpreting such measurements.

\section{Materials and methods}

The concentrations of $\mathrm{Cr}$ and $\mathrm{Ni}$ were determined in lung tissues from 87 unselected necropsies carried out from 1974 to 1978 (71 at the Institute of the University Hospital, Bergmannsheil, Bochum; 16 at the Institute of Legal Medicine, Dortmund). ${ }^{8}$ The same measurements had been made previously on specimens of lung tissue $(23 \mathrm{Cr}$ and $16 \mathrm{Ni}$ determinations) obtained from the Institute of Pathology, University of Münster. ${ }^{9}$ The subjects were adults from the catchment areas of the hospitals who had died from various causes, including six persons from Bochum who had had bronchial carcinoma. In all cases we obtained a crude history of smoking habits, occupation, and place of residence. The cases from the Bochum and the Dortmund areas were combined to form the Ruhr District group. This district has been defined as a particular pollution area.

The tissue specimens were always taken from the same area of the lung, at the lateral base of the right upper lobe. Three similar specimens were each removed from this narrow region to allow calculation of the intraindividual variation in pulmonary $\mathrm{Cr}$ and $\mathrm{Ni}$ concentrations. Strict precautions were taken to 
prevent contamination with metal during specimen collection and processing. These are time consuming but absolutely essential. ${ }^{81011}$

Concentrations of $\mathrm{Cr}$ and $\mathrm{Ni}$ were determined by means of flameless atomic absorption spectrometry after lyophilisation, wet ashing under pressure, chelation, and extraction. We have described our analytical method in detail elsewhere. ${ }^{811}$ Four specimens of $100 \mathrm{mg}$ dry weight were analysed from each tissue, adding standards before ashing. After the sample solution was distributed to two spectrometry cups, each part specimen was measured four times. The final concentration was calculated with the corresponding mean values and linear correlation and expressed as $\mathrm{ng} / \mathrm{g}$ freeze dried tissue. Measured or mean values that varied considerably were rejected (exclusion criteria: coefficient of variation (CV) $\geq 3^{\circ}{ }_{0}$ with four measured values; $r \leq 0.997$ or $\mathrm{CV}$ of the slope and the intercept of the regression line together $\geq 10^{\circ}{ }_{\mathrm{o}}$ ).

Precision was established by random control determination $^{5}$; in the case of $\mathrm{Cr}$ by repeat measurement of three specimens, and with $\mathrm{Ni}$, by a double repeat measurement of six specimens; in both cases after the specimens had been stored for several weeks. The analytical characteristics were: detection limit (threefold variation from five blind values) $\mathrm{Cr} 8$ $\mathrm{ng} / \mathrm{g}, \mathrm{Ni} 5 \mathrm{ng} / \mathrm{g}$ dry weight; precision, $\mathrm{Cr} 1.9 \%, \mathrm{Ni}$ $11 \cdot 7^{\circ}$; accuracy (checked with NBS SRM 1577 bovine liver, $\mathrm{n}=4$ ), $\mathrm{Cr} 106$ (SD 7) $\mathrm{ng} / \mathrm{g}$ dry weight (certification value, 88 (SD 12) $\mathrm{ng} / \mathrm{g}$ ) (the National Bureau of Standards, Washington DC does not provide standard reference material for $\mathrm{Ni}$ determination).

We used ln transformed concentrations for statistical analysis for two reasons. Firstly, the intraindividual variance increased with an increasing within lung mean; this dependency vanished after ln transformation of the data. Secondly, for the investigation of age dependency of $\mathrm{Cr}$ and $\mathrm{Ni}$ concentrations, we first used a non-parametric fit as described in detail elsewhere. ${ }^{8}$ The fitted curves (non-straight lines in figs 1-4) showed strong evidence for a pure linear age dependency of $\ln$ transformed $\mathrm{Cr}$ and $\mathrm{Ni}$ concentrations. Subsequent to this, simple linear regression analysis was used and this gave a fitted straight line with estimated intercepts and slopes as shown in figs $1-4$. There was no significant difference in these slopes between the two regions under consideration.

\section{Results}

The $\mathrm{Cr}$ and $\mathrm{Ni}$ concentrations in lung tissue of the subjects from the Ruhr District were 4.0 and 2.8 times higher than of those from Münster and surrounding areas. Concentrations of $\mathrm{Cr}$ and $\mathrm{Ni}$ were twice as high in men compared with women (table 1 ). All data showed an age dependent increase in $\mathrm{Cr}$ and $\mathrm{Ni}$ concentrations in the lung (about $2.4 \%$ a year for $\mathrm{Cr}$ and about $3 \%$ a year for $\mathrm{Ni}$; table 2). Concentrations of $\mathrm{Cr}$ and $\mathrm{Ni}$ were highly correlated $(r \geq 0.9$, fig 5).

The Bochum group contained six cases of lung

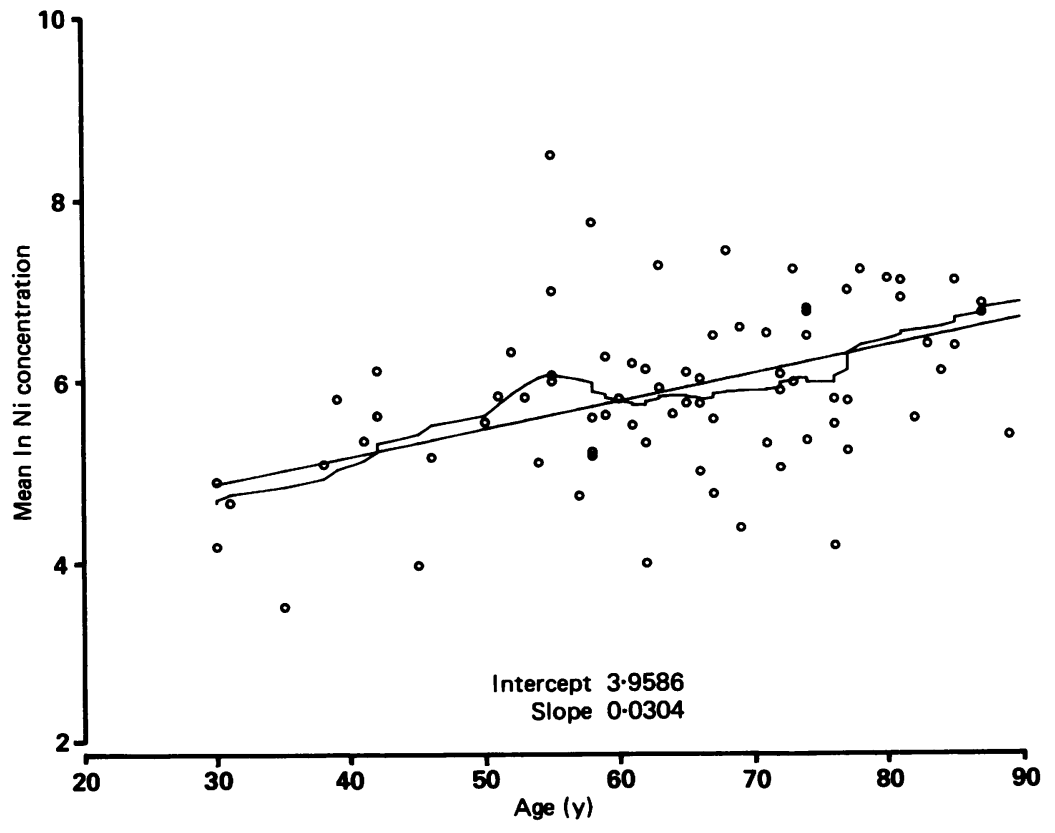

Figure 1 Agev mean ln transformed Ni concentration in lung tissue. Cases from Ruhr district (except cancer cases and cases who died before age 20). 


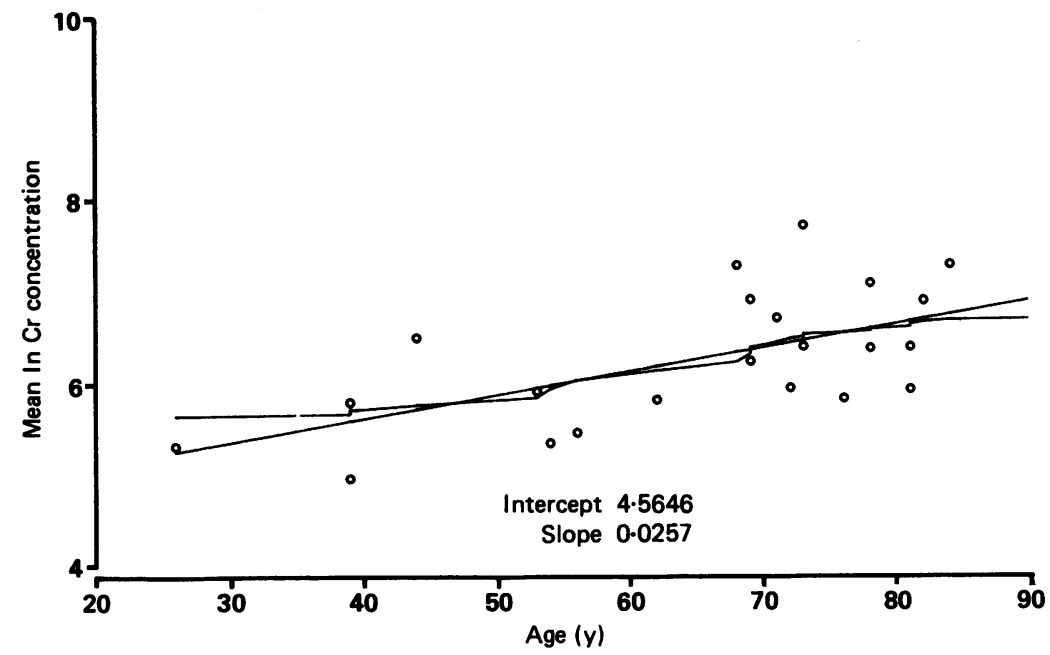

Figure 2 Age v mean ln transformed Cr concentration in lung tissue. Cases from Münster region (except cancer cases and cases who died before age 20). cancer that showed pulmonary $\mathrm{Cr}$ and $\mathrm{Ni}$ concentrations mostly well above a predicted value (table 3 ). One case of bronchial carcinoma had extremely high $\mathrm{Cr}$ and $\mathrm{Ni}$ values; this could be due to occupational exposure as a dental laboratory technician.

Data without the under 20 age range and without the case of bronchial carcinoma with extremely high $\mathrm{Cr}$ and $\mathrm{Ni}$ values can be regarded as representative of the range of values occurring normally. The deviation of $\ln$ transformed $\mathrm{Cr}$ and $\mathrm{Ni}$ values is explained by interindividual variation of more than $90 \%$ and $85^{\circ}{ }_{0}$, and intraindividual variation of only about $10^{\circ}{ }_{0}$ because of a very low analytical error.

\section{Discussion}

Obviously the pulmonary $\mathrm{Cr}$ and $\mathrm{Ni}$ content relates to certain working places (local), to a steady low level exposure to air pollution (regional), and to smoking habits. Smoking might increase a certain metal load of the lung directly by inhalation of the corresponding metals as constituents of tobacco ${ }^{8}$ and indirectly by reducing the lung clearance and causing emphysema. ${ }^{12}$ Probably a greater portion of the chromium added to the atmosphere by man is initially present in the hexavalent oxidation state; some of this will be reduced by organic matter in the air and some will be deposited on vegetation, soils, and in the water. ${ }^{13} \mathrm{With}$ regard to the oxidation state and form of chemical binding during uptake by inhalation, little is known about where and in what amount the accumulated $\mathrm{Cr}$ and $\mathrm{Ni}$ come from.

The $\mathrm{Cr}$ and $\mathrm{Ni}$ content in lung tissue is taken into consideration as a decision criterion regarding the question of the causal connection between a bronchial carcinoma and a corresponding occupational exposure; the exposure time and intensity of

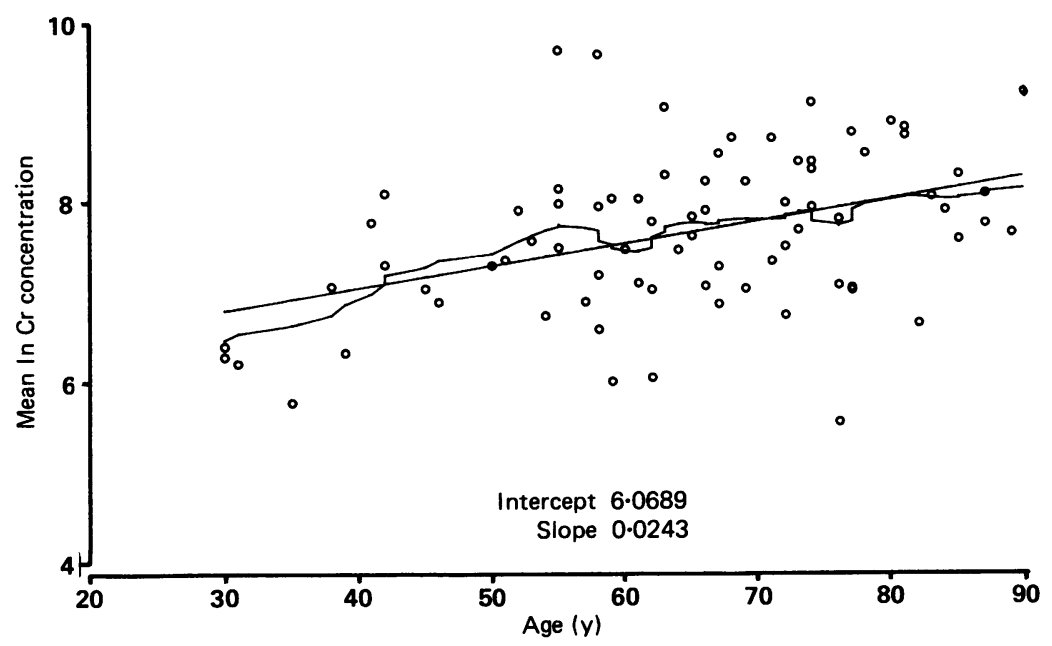

Figure 3 Agev mean ln transformed Cr concentration in lung tissue. Cases from Ruhr district (except cancer cases and cases who died before age 20). 


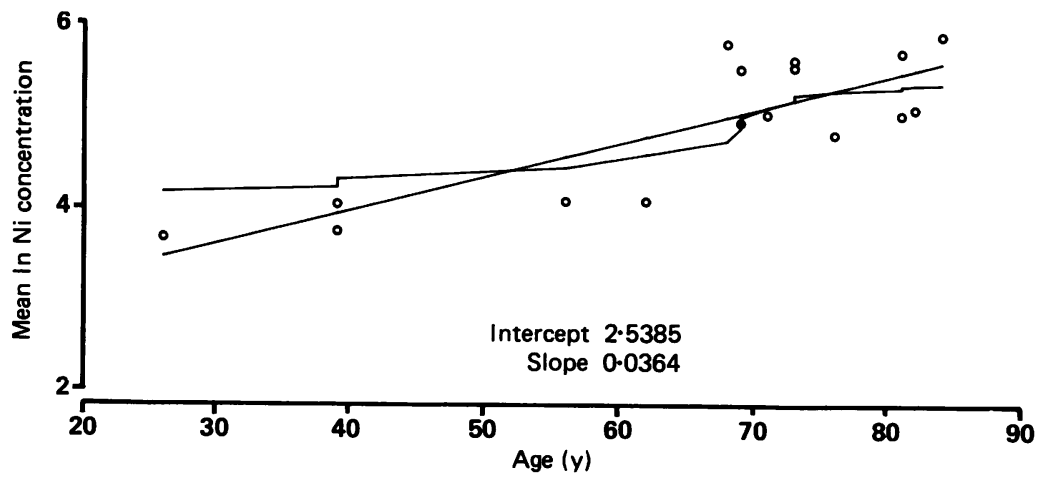

Figure 4 Age v mean ln transformed $\mathrm{Ni}$ concentration in lung tissue. Cases from Münster region (except cancer cases and cases who died before age 20).

exposure to carcinogenic $\mathrm{Cr}$ and $\mathrm{Ni}$ particles and compounds may serve as deciding factors if the metal content clearly exceeds expected values. Usually this information can only be obtained from the report of an expert. Such reports were not available for the cases of bronchial carcinoma in our series, although in view of the high $\mathrm{Cr}$ and $\mathrm{Ni}$ values in some of these cases, it seems plausible that these may be occupational cancers (table 2).

The pitfalls of trace metal analyses are numerous, particularly for $\mathrm{Cr}$ and $\mathrm{Ni}$ measurements in human lung tissue. ${ }^{811}$ The interpretation of these measurements is limited by their validity and reliability. Control of accuracy can be difficult because of the lack of appropriate standard reference materials and recently efforts have been made to provide these materials, including those for $\mathrm{Ni}^{14}{ }^{14} \mathrm{The}$ prevention and the control of extrinsic contamination by $\mathrm{Cr}$ and $\mathrm{Ni}$ during the collection of specimens and processing are discussed elsewhere in detail. ${ }^{811}$

The analysis of wet specimens is obsolete because of the variable water content of tissue, which is known to depend upon physical, chemical, and physiological factors as well as upon different diseases-for example, the water content of the hypostatic base of the lung is much greater than that of the apex. Thus measurements of wet hypostatic lung tissue may yield seemingly low concentrations.

Table 1 Median and range of chromium and nickel concentrations in lung tissue of subjects from Ruhr district and from Münster

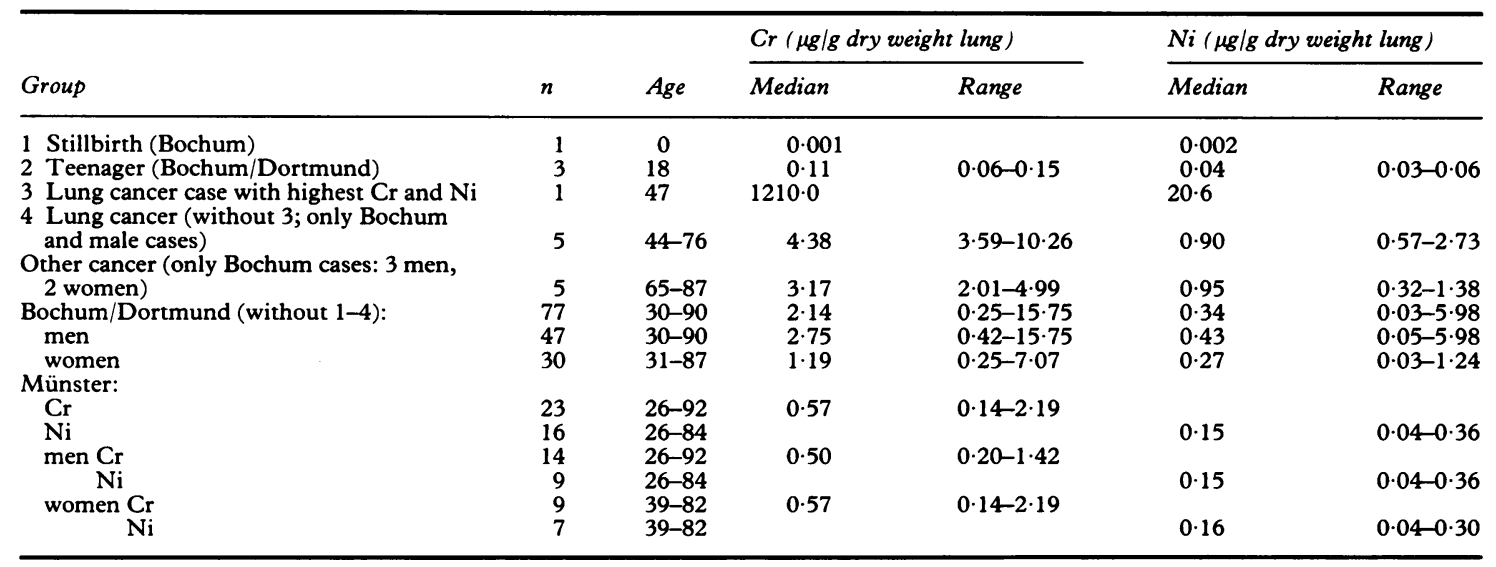

Table 2 Age adjusted $\mathrm{Cr}$ and Ni concentrations ( $\mu \mathrm{g} / \mathrm{g}$ dry wt lung tissue)*

\begin{tabular}{|c|c|c|c|c|c|c|c|c|}
\hline Age (y) & 30 & 45 & 60 & 75 & 30 & 45 & 60 & 75 \\
\hline $\begin{array}{l}\text { Bochum/Dortmund: } \\
\text { men } \\
\text { women } \\
\text { Münster }\end{array}$ & $\begin{array}{l}C r \\
0.90 \\
1 \cdot 10 \\
0.57 \\
0.21\end{array}$ & $\begin{array}{l}1 \cdot 30 \\
1 \cdot 70 \\
0 \cdot 83 \\
0 \cdot 31\end{array}$ & $\begin{array}{l}1 \cdot 90 \\
2 \cdot 40 \\
1 \cdot 20 \\
0.45\end{array}$ & $\begin{array}{l}2 \cdot 70 \\
3.50 \\
1.80 \\
0.66\end{array}$ & $\begin{array}{l}N i \\
0 \cdot 13 \\
0 \cdot 16 \\
0 \cdot 09 \\
0 \cdot 04\end{array}$ & $\begin{array}{l}0 \cdot 21 \\
0 \cdot 26 \\
0 \cdot 14 \\
0 \cdot 07\end{array}$ & $\begin{array}{l}0 \cdot 32 \\
0 \cdot 41 \\
0 \cdot 22 \\
0 \cdot 11\end{array}$ & $\begin{array}{l}0.51 \\
0.66 \\
0.35 \\
0.19\end{array}$ \\
\hline
\end{tabular}

*Based on the Bochum/Dortmund and the Münster cases without the under 20 age range and the bronchial carcinoma cases (see tables 1-4). 


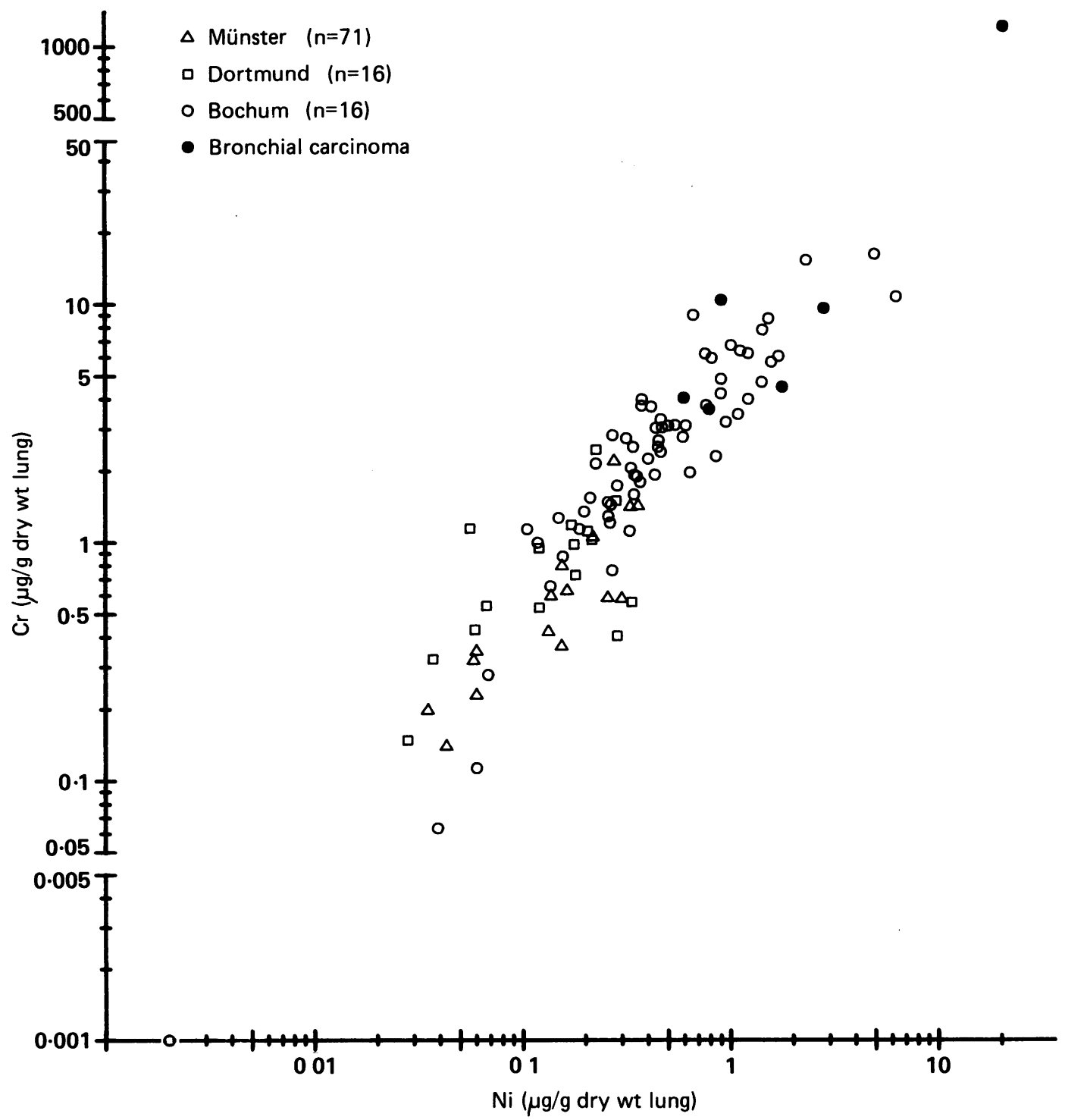

Figure 5 Correlation between $\mathrm{Cr}$ and Ni concentration in postmortem specimens of lung ( $r \geqslant 0.9)$.

Furthermore, it is not possible to calculate dry weight from wet weight using a fixed factor; the ratio of wet to dry lung tissue before and after lyophilisation $(n=258)$ resulted in a mean factor of 5.65 , a variance of $16 \%$, and a range of $4 \cdot 1$ to $12 \cdot 8 .^{8}$ When specimens were preserved in formalin $(n=23)$, the mean factor was 6.8 with a variance of $19 \% .^{10}$

Until now, handling of intraindividual variation in pulmonary $\mathrm{Cr}$ and $\mathrm{Ni}$ concentration has been unsatisfactory, ${ }^{4-8}$ with restrictions on reproducibility and comparability of the measurements. In this connection, it is remarkable that even the healthy lung shows regional differences in ventilation; these are particularly pronounced in pulmonary disease. The problem of intraindividual variation in pulmonary $\mathrm{Cr}$ and $\mathrm{Ni}$ concentration cannot be solved by investigating whole lungs or lung lobes, because of the considerable lack of homogeneity-for example, parenchyma, airways, blood vessels and contents - of this tissue. Thus if relatively small specimens of tissue are analysed, the pulmonary $\mathrm{Cr}$ and $\mathrm{Ni}$ concentrations measured might be different from those of the whole lung. To obtain the real overall pulmonary $\mathrm{Cr}$ and $\mathrm{Ni}$ concentration as exactly as possible other 
Table 3 Bronchial carcinoma cases

\begin{tabular}{|c|c|c|c|c|c|c|c|c|c|}
\hline $\begin{array}{l}\text { Case } \\
\text { No }\end{array}$ & $\begin{array}{l}\text { Age } \\
(y)\end{array}$ & $\begin{array}{l}\text { Classification } \\
\text { of carcinoma }\end{array}$ & $\begin{array}{l}\text { Chromium } \\
\text { ( } \mu \text { g/g dry } \\
\text { weight/lung) }\end{array}$ & $D^{\star}$ & $\begin{array}{l}\text { Nickel } \\
\text { ( } \mu \text { g/g dry } \\
\text { weight/lung) }\end{array}$ & $D$ & $\begin{array}{l}\text { Occupation } \\
\text { (duration) }\end{array}$ & $\begin{array}{l}\text { Daily } \\
\text { smoking } \\
\text { (No of } \\
\text { cigarettes) }\end{array}$ & $\begin{array}{l}\text { Populat } \\
\text { of place } \\
\text { of } \\
\text { residenc }\end{array}$ \\
\hline $240 / 86$ & 44 & Adenocarcinoma & $10 \cdot 3$ & 720 & 0.907 & 350 & $\begin{array}{l}\text { Oven bricklayer } \\
\text { (26 years) }\end{array}$ & $\begin{array}{l}40-60 \\
10-20 \text { (since } 1979 \text { ) }\end{array}$ & 390000 \\
\hline $213 / 85$ & 47 & Small cell & $1210 \cdot 0$ & 89000 & $20 \cdot 6$ & 9300 & $\begin{array}{l}\text { Dental laboratory } \\
\text { technician ( } 28 \text { years) }\end{array}$ & $20-40$ & 155000 \\
\hline $\begin{array}{r}63 / 85 \\
325 / 84\end{array}$ & $\begin{array}{l}56 \\
61\end{array}$ & $\begin{array}{l}\text { Small cell } \\
\text { Epidermoid, low grade }\end{array}$ & $\begin{array}{l}3 \cdot 6 \\
9 \cdot 50\end{array}$ & $\begin{array}{r}64 \\
400\end{array}$ & $\begin{array}{l}0.791 \\
2 \cdot 83\end{array}$ & $\begin{array}{l}120 \\
750\end{array}$ & $\begin{array}{l}\text { Coal miner ( } 30 \text { years) } \\
\text { Crane operator, } \\
\text { steelworker ( } 25 \text { years) }\end{array}$ & $\begin{array}{l}10-12 \\
50\end{array}$ & $\begin{array}{l}175000 \\
390000\end{array}$ \\
\hline $191 / 87$ & 61 & $\begin{array}{l}\text { Large cell, } \\
\text { undifferentiated }\end{array}$ & $4 \cdot 45$ & 130 & $1 \cdot 78$ & 430 & Coal miner (20 years) & 40 & 390000 \\
\hline $354 / 85$ & 76 & Small cell & 4.01 & 46 & 0.597 & 13 & Coalminer ( 43 years) & 6 (and 6 pipes) & 390000 \\
\hline
\end{tabular}

$\star D=\%$ Difference from the age, sex, and region adjusted mean.

†An indication of high air pollution.

errors must be minimised by using a standardised analytical method (including specimen taking, storing, and transport), always investigating the same pulmonary region (which should be located remote from alterations such as hypostasis), and analysing several specimens from that region with the intention of reducing methodological intrapulmonary variation in $\mathrm{Cr}$ and $\mathrm{Ni}$ concentration to an acceptable degree, and gaining an insight into the reliability of the method.

We were able to show that the pulmonary $\mathrm{Cr}$ and $\mathrm{Ni}$ content of a person depends upon age, sex, and residential area. As the degree of pollution of residential and industrial areas varies, the dependency is also related to historical periods. Remarkably, the age dependency of the logarithmic values of pulmonary $\mathrm{Cr}$ and $\mathrm{Ni}$ concentration seems to have a similar slope regardless of sex and the degree of regional air pollution, ${ }^{89}{ }^{15}$ although the $\mathrm{Cr}$ and $\mathrm{Ni}$ load of men and women differs much more in polluted than in nonpolluted areas. By means of the age dependent slope of pulmonary $\mathrm{Cr}$ and $\mathrm{Ni}$ accumulation in humans it is possible to calculate expected values of pulmonary $\mathrm{Cr}$ and $\mathrm{Ni}$ concentrations adjusted for sex and region by studying relatively small populations from the same sex group and homogeneous residential areas. People highly exposed through their occupation will interfere with the calculation of expected concentrations. As a consequence, it is possible to prove the difference between an expected and an observed concentration; this may have value in interpretation of such measurements in an individual case and in epidemiological studies.

Requests for reprints to: Dr H Kollmeier, Dir and Prof, Bundesanstalt für Arbeitsschutz, Vogelpothsweg 50-52, 4600 Dortmund 1, FRG.
1 Raithel HJ, Schaller KH, Reith A, Svenes KB, Valentin H. Investigations on the quantitative determination of nickel and chromium in human lung tissue. Industrial medical, toxicological, and occupational medical expertise aspects. Int Arch Occup Environ Health 1988;60:55-66.

2 Turhan U, Wollburg C, Angerer J, Szadkowski D. Der Nickelgehalt menschlicher Lungen und seine Bedeutung für die Beurteilung berufsbedingter Bronchial-karzinome. Arbeitsmed Sozialmed Präventivmed 1985;20:277-81.

3 Zober A. On the problems of evaluating bronchial carcinoma after exposure to chromium compounds. Int Arch Occup Environ Health 1979;43:107-21.

4 Raithel HJ, Ebner G, Schaller KH, Schellmann B, Valentin H. Problems in establishing norm values for nickel and chromium concentrations in human pulmonary tissue. $\mathrm{Am} \mathrm{J}$ Ind Med 1987;12:55-70.

5 Rezuke WN, Knight JA, Sunderman FW. Reference values for nickel concentrations in human tissues and bile. Am J Ind Med 1987;11:419-26.

6 Zielhuis RL, Stijkel A, Verberk MM, van de Poel-Boot M. Health risks to female workers in occupational exposure to chemical agents. Berlin: Springer-Verlag, 1984:54-6.

7 Kollmeier H, Seemann J, Müller KM, Rothe G, Wittig P. Increased chromium and nickel content in lung tissue and bronchial carcinoma. Am J Ind Med 1987;11:659-69.

8 Kollmeier H, Müller KM, Seemann J, et al. Untersuchungen zur Chrom- und Nickel-Belastung der Lunge. Bremerhaven: Wirtschaftsverlag NW, 1988:1-222. (BAU Fb No 548.)

9 Kollmeier H, Witting C, Seemann J, Wittig P, Rothe G. Increased chromium and nickel content in lung tissue. $J$ Cancer Res Clin Oncol 1985;110:173-6.

10 Seemann J, Wittig P, Kollmeier H, Müller KM, Schejbal V. Trace metal analysis of chromium and nickel in lung tissue fixed and stored in formalin. Pathol Res Pract 1990;186: 197-201.

11 Seemann J, Wittig P, Kollmeier H, Rothe G. Analytische Bestimmung von $\mathrm{Cd}, \mathrm{Pb}, \mathrm{Zn}, \mathrm{Cr}$ und $\mathrm{Ni}$ in Humangewebe. Laboratoriumsmedizin Med 1985;9:294-9.

12 Anttila S, Kokkonen P, Pääkkö P, et al. High concentrations of chromium in lung tissue from lung cancer patients. Cancer 1989;63:467-73.

13 Cary EE. Chromium in air, soil and natural waters. In: Langards $\mathrm{S}$, ed. Biological and environmental aspects of chromium. Amsterdam: Elsevier Biomedical Press, 1982:49-64.

14 Belliardo JJ, Wagstaffe PJ. BCR reference materials for food and agricultural analysis: an overview. Fresenius' Zeitschrift für Analytische Chemie 1988;332:533-8.

15 Sunderman FW Jr, Nomoto S, Nechay M. Nickel metabolism in myocardial infarction: Measurements of nickel in human tissues. In: Hemphill DD, ed. Trace substances in environmental health. Vol 4. Columbia: University of Missouri Press, 1971:352-6.

Accepted 13 March 1990

(1)

